\title{
Pengaruh Total Assets Turnover dan Current Ratio terhadap Return on Assets pada Perusahaan Properti dan Real Estate di BEI (2014-2018)
}

The effect of total assets turnover and current ratio on return on assets at properti and real estate companies on IDX (2014-2018)

\section{Hanna Arsyanti}

Program Studi D3 Keuangan dan Perbankan, Politeknik Negeri Bandung

E-mail: hanna.arsyanti98@gmail.com

\section{Fifi Afiyanti Tripuspitorini}

Jurusan Akuntansi, Politeknik Negeri Bandung

E-mail: fifi.afiyanti@polban.ac.id

\section{Djoni Djatnika}

Jurusan Akuntansi, Politeknik Negeri Bandung

E-mail: djoni.djatnika@polban.ac.id

\begin{abstract}
The research in this final project was to know and analyze The Effect of Total Assets Turnover and Current Ratio to Return On Assets in Property and Real Estate Companies on the Indonesian Stock Exchange in the periode 2014-2018. The type of data used is secondary data in the form of the company's annual financial statement. In the research, there are 7 Property and Real Estate Companies on the Indonesia Stock Exchange which are sampled research. The research method used is descriptive and quantitative research. The test is done by panel data regression which eviews 10. The selected panel data regression method is Fixed Effect Model. The research result show that Total Assets Turnover has a positive impact to Return On Assets and Current Ratio has not impact to Return On Assets. Total Assets Turnover and Current Ratio have a simultaneous effect to Return On Assets.
\end{abstract}

Keywords: total assets turnover, current ratio, return on assets

\section{Pendahuluan}

Perusahaan yang berkembang pesat tidak akan terlepas dari aktivitas yang dijalaninya, maka dari itu aktivitas suatu perusahaan yang baik akan menghasilkan suatu perkembangan yang baik juga terhadap usahanya. Perkembangan suatu usaha juga dipengaruhi oleh pertumbuhan ekonomi. Pada tahun 2018, pertumbuhan ekonomi sedang mengalami kenaikan yang sangat dahsyat dibandingkan dengan tahun-tahun sebelumnya. Seperti yang dinyatakan oleh Kepala Badan Pusat Statistik (BPS) bahwa "Pertumbuhan ekonomi Indonesia pada tahun 2018 mencapai 5,17 persen. Angka itu lebih tinggi dibandingkan dengan tahun-tahun sebelumnya. Dimana pada tahun 2014 hanya mencapai 5,01 persen saja. Perekonomian Indonesia pada tahun 2018 ditopang oleh pertumbuhan dari beberapa sektor, salah satunya adalah sektor industri jasa".

Salah satu sektor industri jasa yaitu sub sektor properti dan real estate ditahun 2018 sedang mengalami pertumbuhan yang kurang memuaskan, hal ini dinyatakan oleh Kementrian Keuangan pada Kontan.co.id bahwa "Meski tumbuh stabil, tetapi masih kurang menggembirakan atau masih dibawah rata-rata nasionalnya. Sejak 2016 sudah agak melandai". Berdasarkan data 
Kemkeu, realisasi pertumbuhan domestik bruto (PDB) di 2016 sebesar 4,7\%, di 2017 sebesar 3,7\% dan pertumbuhan di kuartal III 2018 sebesar 3,4\%. Hal ini menjadi alasan mengapa PDB pada perusahaan sub sektir properti dan real estate tidak berpengaruh pada pertumbuhan ekonomi. Dibuktikan juga oleh perkembangan Return On Assets di perusahaan sub sektor propeti dan real estate periode 2014-2018.

Return On Assets (ROA) pada Perusahaan Properti dan Real Estate mengalami fluktuatif setiap tahunnya. Tetapi pada tahun 2018, Return On Assets (ROA) pada Perusahaan Properti dan Real Estate mengalami penurunan yang drastis dari tahun-tahun sebelumnya. Hal ini menyebabkan kemampuan Perusahaan Properti dan Real Estate untuk memperoleh laba dengan menggunakan aset yang dimilikinya rendah sehingga berpotensi menimbulkan kerugian. Pasalnya pada tahun 2014-2017, Return On Assets (ROA) yang dihasilkan cukup baik dibandingkan dengan tahun 2018, yang dimana tingginya persentase ROA mengindikasikan efektivitas dan efisiensi penggunaan aset perusahaan untuk menghasilkan laba bersih yang maksimal.

Menurut Barus dan Leliani (2013) besar kecilnya Return On Assets (ROA) dapat dipengaruhi oleh rasio keuangan lainnya seperti Total Assets Turnover (TATO) dan Current Ratio. Perkembangan pada rata-rata Total Assets Turnover (TATO) memperlihatkan bahwa pada Perusahaan Properti dan Real Estate mengalami penurun di setiap tahunnya. Hal ini menyebabkan penjualan bersih masih belum efektif dan perputaran semua aset semakin melambat sehingga mengakibatkan kinerja keuangan perusahaan tidak baik. Jika persentase Total Assets Turnover (TATO) semakin besar, maka efektivitas penggunaan aktiva perusahaan akan semakin baik dalam menghasilkan pendapatan yang kemudian berpengaruh juga pada peningkatan laba bersih. Sehingga meningkat Total Assets Turnover (TATO) seharusnya berpengaruh positif untuk Return On Assets (ROA). Namun kenyataannya Perusahaan Properti dan Real Estate mengalami penurunan TATO pada tahun 2016 hingga 2017, sedangkan persentase ROA meningkat ditahun yang sama. Current Ratio pada Perusahaan Properti dan Real Estate disetiap tahunnya juga mengalami kenaikan hal ini akan berpengaruh terhadap profitabilitas pada perusahaan tersebut. Ditahun 2014-2015 mengalami penurunan yang diikuti oleh penurunan Return On Assets (ROA). Pada tahun 2016-2017 Current Ratio mengalami kenaikan dan nilai Return On Assets juga mengalami kenaikan.

Selain itu terjadi beberapa research gap pada hasil penelitian terdahulu mengenai pengaruh Total Assets Turnover dan Current Ratio terhadap Return On Assets. Ridho (2015) menyatakan bahwa Total Assets Turnover tidak berpengaruh terhadapat Return On Assets, sedangkan penelitian Firza \& Ade (2018) dan Herma, Suratno dan Suyanto (2016) menyatakan bahwa Total Assets Turnover berpengaruh signifikan terhadap Return On Assets. Hasil penelitian Ridho (2015) menyatakan bahwa Current Ratio berpengaruh terhadap Return On Assets. Penelitian Anita \& Teguh (2013) dan Herman (2016) menyatakan bahwa Current Ratio tidak berpengaruh terhadap Return On Assets .

Berdasarkan uraian latarbelakang dan fenomena tersebut bahwa beberapa Perusaha Properti dan Real Estate terdapat perbedaan teori yang ada, maka penulis tertarik untuk melakukan penilitian dengan judul "PENGARUH TOTAL ASSETS TURNOVER DAN CURRENT RATIO TERHADAP RETURN ON ASSETS PADA PERUSAHAAN PROPERTI DAN REAL ESTATE DI BEI (2014-2018)".

\section{Kajian Pustaka}

\subsection{Total Assets Turnover}

Menurut Hery (2015), "Total Assets Turnover merupakan rasio yang digunakan untuk 
mengukur keefektifan total aset yang dimiliki perusahaan dalam menghasilkan penjualan. Semakin tinggi rasio perputaran total aset menunjukkan semakin efektif perusahaan dalam penggunaan aktivanya untuk menghasilkan total penjualan bersih. Semakin efektif perusahaan menggunakan aktiva yang menghasilkan penjualan bersih menunjukkan semakin baik kinerja yang dicapai oleh perusahaan".

Hasil penelitian ini didukung oleh Firza dan Ade (2018) dengan judul Pengaruh Current Ratio dan Total Assets Turnover terhadap Return On Assets pada Perusahaan Plastik dan Kemasan tahun 2012-2016 bahwa Total Assets Turnover berpengaruh positif dan signifikan terhadap Return On Assets.

\subsection{Current Ratio}

Menurut Kasmir (2010:110), “Current Ratio merupakan rasio yang digunakan untuk megukur kemampuan perusahaan dalam memenuhi kewajiban jangka pendeknya yang segera jatuh tempo dengan menggunakan total aset lancar yang tersedia. Semakin tinggi Current Ratio suatu perusahaan berarti semakin kecil resiko kegagalan perusahaan dalam memenuhi kewajiban jangka pendeknya. Hal ini akan mengurangi ketidakpastian investor, tetapi mengindikasikan adanya dana yang menganggur (idle cash).Rasio lancar dihitung sebagai hasil bagi antara total aset dengan total kewajiban lancar".

Hasil penelitian ini didukung oleh Hasmirati mengenai Pengaruh Current Ratio dan Debt to Equity Ratio terhadap Return On Assets pada Perusahaan manufaktur yang terdaftar di BEI tahun 2011-2014 bahwa Current Ratio secara parsial berpengaruh negatif dan signifikan terhadap Return On Assets.

\subsection{Return On Assets}

Menurut Hery (2015:226), "Return On Assets merupakan rasio profitabilitas yang menunjukkan seberapa besar kontribusi aset atau sumber daya yang dimiliki perusahaan dalam menciptakan laba bersih. Semakin tinggi Return On Assets, maka semakin baik perusahaan dalam mengelola total aset untuk menghasilkan keuntungan juga menandakan semakin baik kinerja perusahaan tersebut dalam menghasilkan laba bersih".

Laba bersih yang dimaksud dalam rasio keuangan yaitu laba setelah pajak atau di dalam laporan keuangan sering juga disebut sebagai laba tahun berjalan. Sementara total aset yang dimaksud dalam rasio keuangan yaitu seluruh harta kekayaan yang dimiliki perusahaan baik yang bersumber dari modal sendiri (equity) maupun utang (debt). Return On Assets dihitung sebagai hasil bagi antara laba setelah pajak dengan total asset (Prakarsa dan Setiawan, 2018).

\section{Metode Penelitian}

"Metode penelitian yang digunakan dalam penelitian ini yaitu metode deskriptif dan kuantitatif. Data kuantitatif atau statistik dengan tujuan untuk menguji hipotesis yang telah ditetapkan. Objek penelitian yang digunakan dalam penelitian ini adalah perusahaan properti dan real estate yang terdaftar di Bursa Efek Indonesia periode 2014-2018”. Populasi dalam penelitian ini berjumlah 65 perusahaan sedangkan sampe yang diambil berjumlah 7 perusahaan dengan menggunakan teknik purposive sampling. Jenis data dalam penelitian bersifat data panel, karena gabungan antara data"runtut waktu dan data cross section serta sumber data yang digunakan berupa data sekunder yang berasal dari laporan keuangan tahunan perusahaan sub sektor properti dan real estate.

\subsection{Operasional Variabel}

1. Variabel Independen

Variabel independen adalah variabel yang memepengaruhi atau yang menjadi sebab 
perubahannya atau timbulnya variabel depeden / terikat (Sugiyono, 2016). Variabel bebas yang digunakan dalam penelitian yaitu :

$>$ Total Assets Turnover yaitu rasio aktivitas yang menggambarkan perputaran total aset dan menghitung penjualan yang diperoleh dari total aset perusahaan.

$$
\text { TATO }=\frac{\text { Penjualan }}{\text { Rata }- \text { rata total aset }} \times 100 \%
$$

Current Ratio yaitu rasio likuiditas yang menggambarkan aset lancar perusahaan yang digunakan untuk memenuhi kewajiban lancarnya yang segera jatuh tempo.

$$
\text { Current Ratio }=\frac{\text { Aset Lancar }}{\text { Kewajiban Lancar }} \times 100 \%
$$

\section{Variabel Dependen}

Variabel dependen merupakan variabel yang dipengaruhi atau yang menjadi akibat, karena adanya variabel bebas (Sugiyono, 2016). Variabel dependen yang digunakan dalam penelitian ini adalah Return On Assets.

$$
R O A=\frac{\text { Laba setelah pajak }}{\text { Total aktiva }} \times 100 \%
$$

\subsection{Teknik Analisis Data}

\section{Metode Deskriptif}

Tujuan digunakan metode deskriptif ini adalah untuk membuat deskripsi atau gambaran mengenai fakta-fakta yang disajikan dalam tabel, grafik dan presentasi. Metode deskriptif dalam penelitian ini dibantu dengan Ms. Excel. Dalam penelitian ini, data yang akan dianalisis secara deskriptif yaitu perkembangan Total Assets Turnover, Current Ratio dan Return On Assets pada Perusahaan Properti dan Real Estate di Bursa Efek Indonesia periode 2014-2018.

\section{Metode Kuantitatif}

Metode kuantitatif dalam penelitian ini dibantu dengan Eviews 10. Dalam penelitian ini, data yang akan dianalisis secara kuantitatif yaitul pengaruh Total Assets Turnover dan Current Ratio terhadap Return On Assets pada Perusahaan Properti dan Real Estate di Bursa Efek Indonesia periode 2014-2018. Data yang digunakan dalam penelitian ini merupakan data panel karena terdapat gabungan antara data rentang waktu (time series) dengan data deret lintang (cross section).

Berikut ini didapat persamaan regresi data panel yang ditentukan oleh fixed effect model yang digunakan dalam penelitian ini yaitu :

$$
Y_{i t}=\alpha+\beta_{1} X_{i t}+\beta_{2} X_{2 i t}+\cdots+\beta_{n} X_{n i t}+e_{i t}
$$

Keterangan :

Yit $=$ Variabel Terikat

$\alpha=$ Konstanta (Intercept)

$\beta=$ Koefisien Regresi (Slope)

Xit $=$ Variabel Bebas

i $=$ Entitas ke i

$\mathrm{t}=$ Periode ke $\mathrm{t}$ 
e $=$ Kesalahan Pengganggu, diasumsikan 0

\section{Hasil dan Pembahasan}

\subsection{Analisis Deskriptif}

\section{Perkembangan Total Assets Turnover}

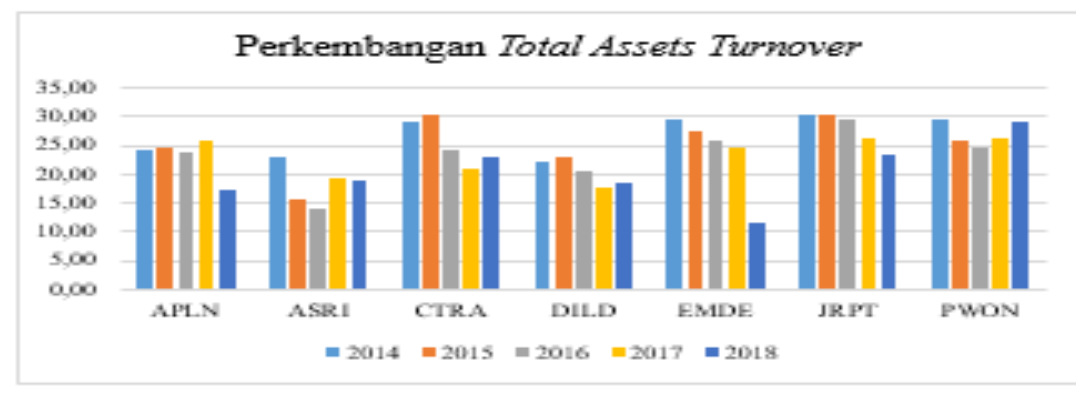

Gambar 1. Perkembangan TATO Perusahaan Properti dan Real Estate Sumber: Data sekunder yang diolah

Berdasarkan grafik diatas, dapat dijelaskan bahwa perkembangan Total Assets Turnover pada Perusahaan Properti dan Real Estate ditahun 2014-2018 berfluktuasi. Perusahaan yang mengalami perkembangan Total Assets Turnover dengan stabil yaitu PT. Pakuwon Jati Tbk dengan nilai sebesar $83,14 \%$. Hal ini disebabkan karena perusahaan mampu menggunakan aset yang dimiliki secara efektif sehingga dapat menyebabkan kenaikan pada Total Assets Turnover. Perkembangan Total Assets Turnover dengan tidak stabil yaitu PT. Megapolitan Development Tbk dengan memperoleh nilai sebesar 11,48\%. Hal ini disebabkan karena perusahaan belum mampu mengelola semua aset yang dimilikinya dengan efektif.

\section{Perkembangan Current Ratio}

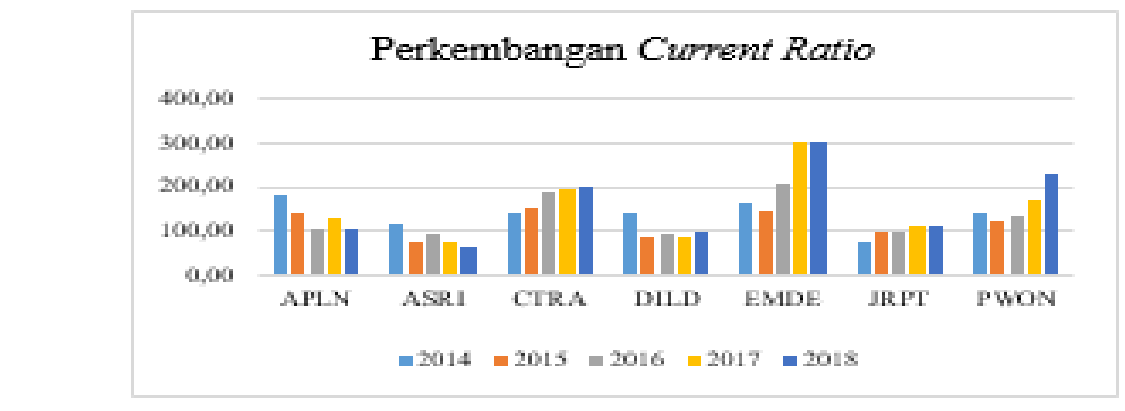

Gambar 2. Perkembangan Current Ratio Perusahaan Properti dan Real Estate

Sumber: Data diolah

Dari grafik diatas dapat dijelaskan bahwa perkembangan Current Ratio pada Perusahaan Properti dan Real Estate berfluktuasi dari tahun 2014-2018. Perusahaan yang mengalami perkembangan Current Ratio dengan stabil dengan memperoleh nilai sebesar 303,33\% yaitu PT. Megapolitan Developmet Tbk. Hal ini disebabkan karena perusahaan mampu melakukan pengelolaan likuiditas dengan baik dan mengurangi resiko kerugian serta dapat menjaga cadangan dana yang dimiliki. Perusahaan yang mengalami perkembangan Current Ratio dengan tidak stabil dengan memperoleh nilai sebesar 65,18\% yaitu PT. Alam Sutera Realty Tbk. Hal ini menunjukkan bahwa perusahaan tersebut belum mampu melakukan pengelolaa likuiditas dengan baik. 


\section{Perkembangan Return On Assets}

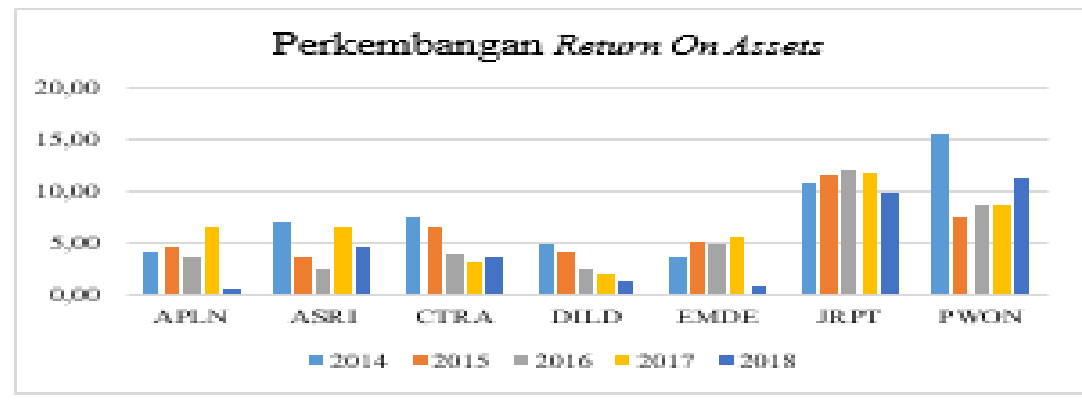

Gambar 3. Perkembangan ROA Perusahaan Propeti dan Real Estate

Sumber: Data diolah

Dari grafik diatas, dapat dijelaskan bahwa perkembangan Return On Assets pada Perusahaan Properti dan Real Estate di Bursa Efek Indonesia berfluktuasi di tahun 20142018. Perkembangan Return On Assets tertinggi dengan nilai sebesar 15,50\% dicapai oleh dan PT. Pakuwon Jati Tbk. Hal ini menunjukkan bahwa perusahaan tersebut mampu mendapatkan keuntungan yang maksimal yang diperoleh dari semua aset perusahaan dan dapat memperluas kegiatan usaha. Keuntungan yang tidak stabil akan menimbulkan risiko kerugian yang cukup besar bagi suatu perusahaan sehingga dapat menghambat kegiatan operasional perusahaan. Perkembangan Return On Assets terendah dengan nilai sebesar 0,65\% dicapai oleh PT. Agung Podomoro Land Tbk. Hal ini dikarenakan belum mampu mendapatkan keuntungan yang maksimal yang diperoleh dari semua aset perusahaan yang dimilikinya.

\subsection{Metode Kuantitatif}

\subsubsection{Model Analisis Data}

\subsubsection{Analisis Regresi Data Panel}

Analisis regresi data panel digunakan untuk menguji pengaruh antara variabel independen yaitu Total Assets Turnover dan Current Ratio terhadap variabel dependen yaitu Return On Assets. Hasil uji regresi data panel ini didapatkan dari model FEM dan uji asumsi klasik.

Tabel 1. Hasil regresi data panel

Dependent Variable: ROA

Method: Panel Least Squares

Date: $04 / 01 / 20$ Time: $12: 53$

Sample: 20142018

Periods included: 5

Cross-sections included: 7

Total panel (balanced) observations: 35

\begin{tabular}{ccccc}
\hline \hline Variable & Coefficient & Std. Error & t-Statistic & Prob. \\
\hline \hline C & 1.104218 & 1.274880 & 0.866135 & 0.3943 \\
TATO & 0.155070 & 0.025182 & 6.157886 & 0.0000 \\
CR & 0.007405 & 0.006792 & 1.090134 & 0.2857 \\
\hline \hline
\end{tabular}

Sumber: Output Eviews 10 
Berdasarkan pendekatan Fixed Effect Model, dapat diketahui persamaan regresi data panel yaitu sebagai berikut :

$$
\mathrm{ROA}=1,104218+0,155070 \mathrm{TATO}+0,007405 \mathrm{CR}
$$

Persamaan regresi diatas dapat diartikan sebagai berikut :

1. Nilai konstanta dari persamaan regresi data panel tersebut yaitu 1,104218. Nilai ini mempunyai arti bahwa jika nilai variable independen (Total Assets Turnover dan Current Ratio) dianggap sama atau konstan, maka nilai Return On Assets yaitu sebesar 1,104218.

2. Koefisien regresi Total Assets Turnover mempunyai nilai sebesar 0,155070. Nilai ini mempunyai arti bahwa jika variabel Total Assets Turnover mengalami peningkatan 1\% dan nilai variabel independen lainnya (Current Ratio) tetap, maka Return On Assets akan meningkat sebesar 0,155070\%. Koefisien regresi Total Assets Turnover bernilai positif. Hal ini menjelaskan bahwa Total Assets Turnover berbanding lurus dengan Return On Assets.

3. Koefisien regresi Current Ratio mempunyai nilai sebesar 0,007405. Nilai ini mempunyai arti bahwa jika nilai variabel Current Ratio mengalami peningkatan 1\% dan nilai variabel independen lainnya (Total Assets Turnover) tetap, maka Return On Assets akan meningkat sebesar 0,007405\%. Koefisien regresi Current Ratio bernilai positif. Hal ini menjelaskan bahwa Current Ratio berbanding lurus dengan Return On Assets.

\subsection{Penentuan Model Regresi Data Panel}

\section{Uji Chow}

Berikut ini merupakan hasil uji chow dengan menggunakan eviews 10 untuk memilih Common Effect Model atau Fixed Effect Model.

Tabel 2. Uji Chow

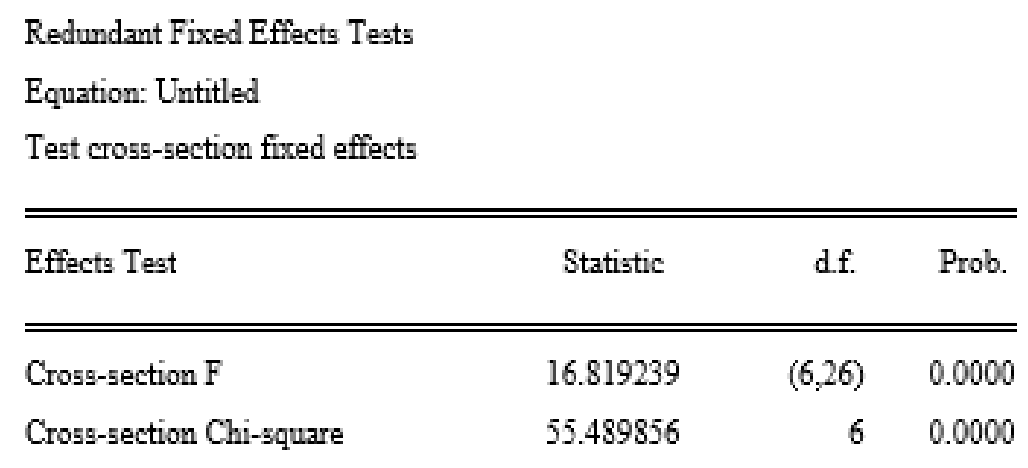

\section{Sumber: Output Eviews 10}

Dari tabel diatas, dijelaskan bahwa nilai probabilitas memiliki nilai yang sama yaitu sebesar 0,0000. Nilai probabilitas tersebut lebih kecil dari 0,05. Dari hasil tersebut, dapat disimpulkan bahwa model yang dipilih dalam uji chow yaitu Fixed Effect Model.

\section{Uji Hausman}

"Berikut ini merupakan hasil uji hausman dengan menggunakan eviews 10 untuk memilih Fixed Effect Model atau Random Effect Model". 


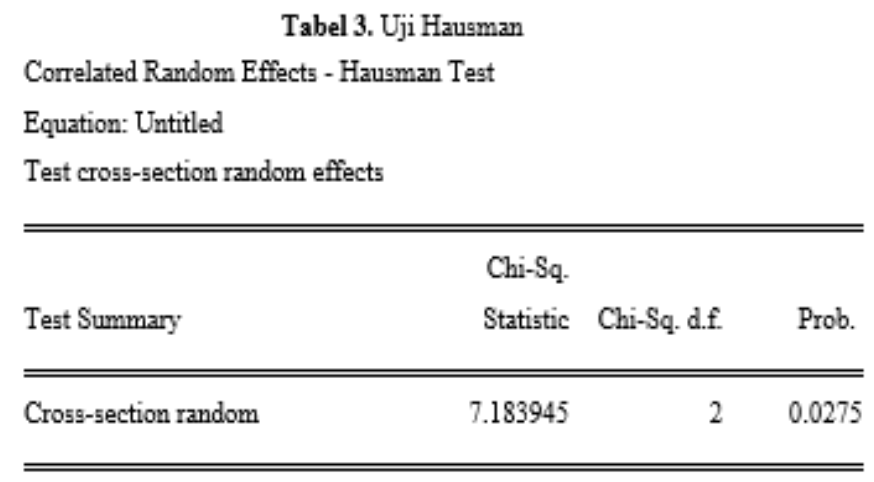

Sumber.:Output Eviews 10

Dari tabel diatas, terdapat pernyataan bahwa nilai probabilitas yaitu 0,0275. Hal ini menjelaskan bahwa Random Effect Model tidak sesuai dalam penelitian ini. Jadi model yang tepat untuk regresi data panel dalam penelitian ini yaitu Fixed Effect Model.

\subsection{Hasil Uji Asumsi Klasik}

\section{1) Uji Normalitas}

Uji normalitas digunakan untuk mengetahui bahwa data yang digunakan dalam penelitian dapat berdistribusi normal. Untuk mengetahui bahwa residual data dalam penelitian ini berdistribusi dengan normal, dilakukan dengan menggunakan pengujian Probabilitas.

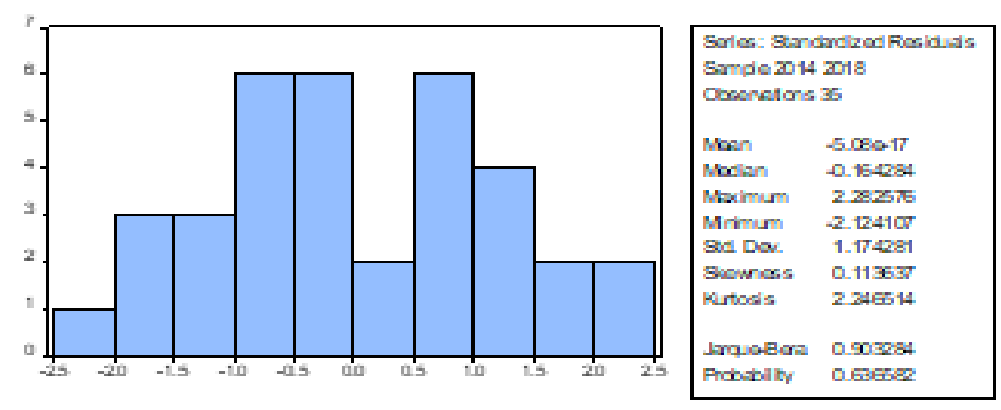

Gambar 4. Hasil Uji Normalitas

Sumber: Output Eviews 10

Berdasarkan gambar tersebut, dapat dilihat bahwa nilai nilai probabilitasnya yaitu sebesar 0,636582. Hal ini menunjukkan bahwa nilai dan probabilitas lebih besar dari 0,05 sehingga data penelitian ini berdistribusi normal atau dapat dikatakan bahwa uji normalitas telah terpenuhi dalam penelitian ini.

\section{2) Uji Multikolinearitas}

Uji multikolinearitas memiliki tujuan untuk menguji apakah dalam model regresi terdapat korelasi antar variable bebas.

Tabel 4. Uji Multikolinearitas

\begin{tabular}{|c|c|c|}
\hline & TATO & CR \\
\hline TATO & 1.000000 & 0.027554 \\
\hline CR & 0.027554 & 1.000000 \\
\hline
\end{tabular}

Sumber: Output Eviews 10

Berdasarkan hasil tabel diatas, dapat dilihat bahwa nilai korelasi antara Total Assets Turnover dan Current Ratio yaitu sebesar 0,027554. Nilai ini lebih kecil dari 0,8 sehingga 


\section{Hanna Arsyanti, Fifi Afiyanti Tripuspitorini, Djoni Djatnika}

hasil model regresi data panel ini tidak terjadi multikolinearitas.

\section{3) Uji Heteroskedastisitas}

Uji heteroskedastisitas digunakan untuk menguji apakah dalam model regresi terjadi ketidaksamaan variansi residual dari satu pengamatan ke pengamatan yang lain.

Tabel 5. Uji Heteroskedastisitas

\begin{tabular}{|c|c|c|c|c|}
\hline \multicolumn{5}{|c|}{ Dependent Variable: RESABS } \\
\hline \multicolumn{5}{|c|}{ Method: Panel Least Squares } \\
\hline \multicolumn{5}{|c|}{ Date: $04 / 01 / 20$ Time: $21: 41$} \\
\hline \multicolumn{5}{|c|}{ Sample: 20142018} \\
\hline \multicolumn{5}{|c|}{ Periods included: 5} \\
\hline \multicolumn{5}{|c|}{ Cross-sections included: 7} \\
\hline \multicolumn{5}{|c|}{ Total panel (balanced) observations: 35} \\
\hline Variable & Coefficient & Std. Error & t-Statigtic & Prob. \\
\hline $\mathrm{C}$ & 0.217199 & 0.618846 & 0.350974 & 0.7284 \\
\hline TATO & 0.010925 & 0.012224 & 0.893703 & 0.3797 \\
\hline $\mathrm{CR}$ & 0.003445 & 0.003297 & 1.044715 & 0.3058 \\
\hline
\end{tabular}

Berdasarkan hasil tabel tersebut, dapat dilihat bahwa nilai probabilitas Total Assets Turnover dan Current Ratio yaitu sebesar 0,3797 dan 0,3058. Nilai probabilitas tersebut lebih besar dari 0,05. Hal ini menjelaskan bahwa data penelitian ini terbebas dari unsur heteroskedastisitas sehingga varian residual dari suatu pengamatan ke pengamatan lainnya sama.

\section{4) Uji Autokorelasi}

Uji autokorelasi digunakan untuk mengetahui apakah dalam suatu model regresi linear terdapat korelasi antara kesalahan dari gangguan pada periode $\mathrm{t}$ dengan gangguan pada periode t sebelumnya.

Tabel 6. Uji Auto Korelasi

\begin{tabular}{|l|r|l|r|}
\hline R-squared & 0.894037 & Mean dependent var & 6.054857 \\
\hline Adjusted R-squared & 0.861433 & S.D. dependent var & 3.607406 \\
\hline S.E. of regression & 1.342841 & Akaike info criterion & 3.644487 \\
\hline Sum squared resid & 46.88380 & Schwarz criterion & 4.044434 \\
\hline Log likelihood & -54.77857 & Hannan-Quinn criter. & 3.782549 \\
\hline F-statigtic & 27.42111 & Durbin-Watson stat & 1.898067 \\
\hline Prob(F-statiatic) & 0.000000 & \\
\hline
\end{tabular}

Berdasarkan hasil tabel tersebut, dapat dilihat bahwa nilai Durbin Watson yaitu 1,898067. Du yang digunakan pada penelitian ini yaitu 1,584 karena jumlah data dalam penelitian ini yaitu sebanyak 35 data dan jumlah variabel independen dalam penelitian ini yaitu sebanyak 2 variabel. Nilai Durbin Watson pada penelitian ini berada di antara du dan 4-du (berada di antara 1,584 dan 2,461) sehingga tidak ada autokorelasi dalam penelitian ini". 


\subsubsection{Koefisien Determinasi}

Nilai koefisien determinasi digunakan untuk mengukur seberapa besar variansi dari variabel dependen dapat diterangkan oleh variabel independen. Pada penelitian ini, koefisien determinasi yang digunakan yaitu adjusted $R^{2}$.

Berdasarkan tabel 6, dapat diketahui bahwa nilai adjusted $\mathrm{R}^{2}$ adalah sebesar 0,861433 Dengan demikian, maka variabel independen dapat menjelaskan atau mempengaruhi variabel dependen pada Perusahaan Properti dan Real Estate tahun 2014-2018 sebesar 86,14\% sedangkan sisanya yaitu sebesar $13,86 \%$ dipengaruhi oleh variabel lainnya.

\subsubsection{Uji Hipotesis}

\section{1) Uji Parsial (Uji-t)}

Uji parsial (uji-t) menunjukkan seberapa jauh pengaruh satu variabel independen secara individual dalam menerangkan variabel dependennya. Hipotesis yang digunakan dalam pengujian ini yaitu :

$\mathrm{HO}_{1} \quad$ : TATO tidak memiliki pengaruh yang isignifikan terhadap ROA.

$\mathrm{Ha}_{1} \quad$ :TATO memiliki pengaruh yang signifikan terhadap ROA.

$\mathrm{HO}_{2}$ : Current Ratio tidak memiliki pengaruh yang signifikan terhadap ROA.

$\mathrm{Ha}_{2}$ : Current Ratio memiliki pengaruh yang signifikan terhadap ROA.

Tabel 7. Uji Pargial (Uji-t)

\begin{tabular}{|ccccc|}
\hline Variable & Coefficient & Std. Error & t-Statistic & Prob. \\
\hline \hline C & 1.104218 & 1.274880 & 0.866135 & 0.3943 \\
TATO & 0.155070 & 0.025182 & 6.157886 & 0.0000 \\
CR & 0.007405 & 0.006792 & 1.090134 & 0.2857 \\
\hline
\end{tabular}

Sumber: Output Evieus 10

Berdasarkan pada tabel diatas, maka dapat disimpulkan bahwa TATO secara parsial berpengaruh terhadap ROA karena nilai probabiliti yang dihasilkan oleh Total Assets Turnover yaitu sebesar 0,0000 yang dimana lebih kecil dari 0,05. Sedangkan Current Ratio secara parsial tidak berpengaruh signifikan terhadap Return On Assets, karena nilai probabiliti yang dihasilkan Current Ratio yaitu sebesar 0,2857 yang dimana nilai probabiliti ini lebih besar dari 0,05 .

\section{2) Uji Simultan (Uji-f)}

Uji simultan atau uji-f ini digunakan untuk melihat seberapa besar pengaruh variabel independen secara keseluruhan atau bersama-sama terhadap variabel dependen. Hipotesis yang digunakan dalam uji simultan (uji-f) ini yaitu :

$\mathrm{H}_{0}$ : TATO dan Current Ratio tidak berpengaruh secara simultan terhadap ROA.

$\mathrm{H}_{1}$ : TATO dan Current Ratio berpengaruh secara simultan terhadap ROA. 
Tabel \&. Uji Simultan (Uji-f)

\begin{tabular}{lrll}
\hline \hline R-squared & 0.894037 & Mean dependent var & 6.054857 \\
Adjusted R-squared & 0.861433 & S.D. dependent var & 3.607406 \\
S.E. of regression & 1.342841 & Alkaike info criterion & 3.644487 \\
Sum squared resid & 46.88380 & Schwarz criterion & 4.044434 \\
Log likelihood & -54.77852 & Hannan-Quinn criter. & 3.782548 \\
F-statistic & 27.42111 & Durbin-Watson stat & 1.898067 \\
Prob(F-statistic) & 0.000000 & & \\
\hline \hline
\end{tabular}

Sumber: Output Evieus 10

Berdasarkan tabel diatas, dapat dilhat bahwa nilai probabilitas (F-statistic) yaitu sebesar 0,000000. Nilai tersebut lebih kecil dari 0,05 yang berarti H1 diterima. Hal ini menjelaskan bahwa Total Assets Turnover dan Current Ratio memiliki pengaruh secara simultan terhadap Return On Assets.

\subsection{Pembahasan Hasil Penelitian}

\section{Pengaruh Total Assets Turonver terhadap Return On Assets}

Berdasarkan hasil penelitian ini, dapat ditunjukkan bahwa Total Asset Turnover memiliki pengaruh secara parsial terhadap Return On Assets. Hal ini ditunjukkan oleh nilai probabilitas Total Assets Turnover yang lebih kecil dari pada 0,05 yaitu 0,0000. Koefisien regresi Total Assets Turnover bernilai positif yaitu sebesar 0,155070. Hal ini menjelaskan bahwa Total Assets Turnover mempunyai hubungan yang searah dengan Return On Assets dan memiliki arti jika Total Assets Turnover mengalami peningkatan maka akan berpengaruh terhadap peningkatan Return On Assets dengan asumsi variabel independen lainnya tetap.

Dalam menjalankan kegiatan operasionalnya, perusahaan tersebut telah mampu menggunakan asetnya untuk menghasilkan penjualan yang baik. Meningkatkan penjualan merupakan salah satu cara untuk menyediakan modal kerja yang cukup. Dengan melakukan peningkatan penjualan, maka total aset yang dimiliki perusahaan akan lebih cepat berputar dan menyebabkan peningkatan pada profitabilitas.

Hasil penelitian ini sejalan dengan penelitian yang dilakukan oleh Thoyib et. al (2018). Penelitian yang dilakukan oleh Thoyib et. al (2018) memperoleh hasil bahwa Total Assets Turnover berpengaruh positif secara parsial terhap Return On Assets.

\section{Pengaruh Current Ratio terhadap Return On Assets}

Berdasarkan hasil penelitian diatas, dapat ditunjukan bahwa Current Ratio tidak memiliki pengaruh secara parsial terhadap Return On Assets pada Perusahaan Properti dan Real Estate. Hal ini ditunjukan bahwa nilai probabilitas Current Ratio lebih besar dari 0,05 yaitu sebesar 0,2857. Koefisien regresi Current Ratio bernilai positif juga yaitu sebesar 0,007405.

Aset lancar yang dimiliki oleh perusahaan properti dan real estate relatif kecil tetapi posisi utang lancarnya mengalami kenaikan. Hal ini membuat Current Ratio tidak memiliki pengaruh terhadap laba yang diperoleh perusahaan, karena aset lancar seperti kas, piutang dan persediaan mengendap dan mengalami perputaran yang lambat dan membuat perusahaan belum mampu mendapatkan keuntungan yang diinginkan. Menurut Kasmir (2016), Penggunaan aset lancar yang kurang bijak dapat mengakibatkan penurunan produktifitas perusahaan, sehingga berpengaruh pada penurunan profitabilitas perusahaan.

Hasil penelitian ini sejalan dengan penelitian yang dilakukan oleh Thoyib et. al (2018). Penelitian yang dilakukan oleh Thoyib et. al (2018) mengatakan bahwa Current Ratio tidak berpengaruh dan tidak signifikan terhadap Return On Assets. 


\section{Pengaruh TATO dan Current Ratio terhadap ROA}

Berdasarkan hasil penelitian yang dilakukan, menunjukkan bahwa Total Assets Turnover dan Current Ratio secara simultan berpengaruh terhadap Return On Assets. Nilai probabilitas (UjiF) yang didapat sebesar $0,000000<0,05$. Hal ini menunjukkan setiap perubahan pada Total Assets Turnover dan Current Ratio akan mempengaruh Return On Assets yang dihasilkan, sehingga jika digabungkan setaip variabel menunjukkan pengaruh yang baik bagi perusahaan.

Penelitian ini sejalan dengan penelitian yang dilakukan oleh Ridho (2014) yang menyatakan bahwa Total Assets Turnover dan Current Ratio memiliki pengaruh secara simultan terhadap Return On Assets.

Pada hasil uji determinasi menunjukkan bahwa persentase pengaruh Total Assets Turnover dan Current Ratio secara simultan terhadap variabel Return On Assets dalam model regresi memiliki pengaruh sebesar $86,14 \%$ sedangkan sisanya yaitu sebesar 13,86\% dipengaruhi oleh variabel lainnya.

\section{Penutup}

\subsection{Kesimpulan}

$>$ Secara parsial Total Assets Turnover memiliki pengaruh positif dan signifikan terhadap Return On Assets.

> Secara parsial Current Ratio tidak memiliki pengaruh terhadap Return On Assets.

$>$ Secara simultan Total Assets Turnover dan Current Ratio berpengaruh signifikan

5.2 Saran terhadap Return On Assets.

$>$ Untuk perusahaan, sebaiknya mampu mengelola aset lancar agar tidak mengendap dan berputar cepat (produktif) serta menghindari dana yang menganggur.

> Untuk peneliti selanjutnya, mengembangkan penelitian ini dengan cara memperpanjang periode penelitian atau menambah variabel baru yang dapat mempengaruhi Return On Assets.

\section{Daftar Pustaka}

Adiko, R. G. (2015). Pengaruh Current Ratio Dan Total Assets Turnover Terhadap ROA Pada Perusahaan Sektor Farmasi Yang Terdaftar Di BEI Periode 2009-2013. Download (diturunkan/diunduh) pada 1 Juli 2020.

Alpi, F. M., \& Gunawan, A. (2018). Pengaruh Current Ratio Dan Total Assets Turnover Terhadap Return On Assets Pada Perusahaan Plastik Dan Kemasan. 30. Download (diturunkan/diunduh) pada 11 Februari 2020.

Barus, A. C., \& Leliani. (2013). Analisis Faktor-Faktor Yang Mempengaruhi Profitabilitas Pada Perusahaan Manufaktur Yang Terdaftar Di Bursa Efek Indonesia. Jurnal Wira Ekonomi Mikroskil, 3. Download (diturunkan/diunduh) pada 1 Maret 2020.

Basuki, A. T., \& Prawoto, N. (2017). Analisis Regresi Dalam Penelitian Ekonomis \& Bisnis : Dilengkapi Aplikasi SPSS \& EVIEWS . Depok: PT Raja Grafindo Persada. Download (diturunkan/diunduh) pada 17 April 2020.

BPS. $\quad$ https:///www.bps.go.id/pressrelease/2019/02/06/1619/ekonomi-indonesia-2018tumbuh-5-17-persen.html. Download (diturunkan/diunduh) pada 5 Maret 2020.

Hasmirati. (2019). Pengaruh Current Ratio dan Debt To Equity Ratio Terhadap Return On Assets Pada Perusahaan Manufaktur Yang Terdaftar Di BEI. 17. Download (diturunkan/diunduh) pada 1 Juli 2020. 
Hery. (2015). Analisis Laporan Kenangan. Yogyakarta: PT BUKU SERU.

Kasmir. (2010). Pengantar Manajemen Keuangan. Jakarta: Penerbit Kencana.

Kasmir. (2016). Analisis Laporan Kenangan. Jakarta: PT Grafindo Persada.

Kompas. (n.d.). Perkembangan di Bidang Properti dan Real Estate. https://properti.kompas.com/read/2018/04/02/153000621/pengembang--propertibisa-jadi-acuan-pertumbuhan-ekonomi. Download (diturunkan/diunduh) pada 5 Juli 2020 .

Prakarsa, R. A., \& Setiawan, S. (2018, October). Pengaruh Profitabilitas, Leverage, Dan Ukuran Perusahaan Terhadap Praktik Perataan Laba (Studi Pada Perusahaan Keuangan Sub Sektor Perbankan Yang Terdaftar Di Bursa Efek Indonesia Periode 2015-2017). In Prosiding Industrial Research Workshop and National Seminar (Vol. 9, pp. 719-727).

Ra'Yan, I. (2018). Analisis Regresi Data Panel Pada Faktor-Faktor Yang Mempengaruhi Tingkat Kemiskinan Provinsi Sulawesi Selatan Tahun 2011-2015. Jurnal Matematika. Download (diturunkan/diunduh) pada 10 Juli 2020.

Setiawan , E. (2015). Pengaruh Current Ratio, Inventory Turnover, Debt to Equity Ratio, Total Assets Turnover, Sales, dan Firm Size terhadap Return On Assets pada Perusahaan Food and Beverage yang terdaftar di Bursa Efek Indonesia periode 2010-2013. Skripsi. Download (diturunkan/diunduh) pada 5 April Juli 2020.

Sugiyono. (2016). Metode Penelitian Kuantitatif, Kualitatif dan R\&D. Bandung: PT Alfabet.

Supardi, H., Suyanti, \& Suyanto. (2016). Pengaruh Current Ratio, Debt To Asset Ratio, Total Assets Turnover Dan Inflasi Terhadap Return On Assets. Jurnal Imiah Akuntansi Fakultas Ekonomi, 2, 26. Download (diturunkan/diunduh) pada 11 Maret 2020.

Thoyib, M., Firmansyah, Amri, D., Wahyudi , R., \& Melin, M. A. (2018). Pengaruh Current Ratio, Debt To Assets Ratio, Debt To Equity Ratio Dan Total Assets Turnover Terhadap ROA Pada Perusahaan Properti dan Real Estate Di BEI. Jurnal Akuntansi. Download (diturunkan/diunduh) pada 11 Maret 2020. 